\title{
ДИНАМІЧНЕ ЗМІЦНЕННЯ ПОВЕРХОНЬ КОМПОЗИТНИХ ДЕТАЛЕЙ ТЕРТЯ ДРУКАРСЬКИХ МАШИН ТОНКИМ ШЛІФУВАННЯМ
}

( А. П. Гавриш, д.т.н., професор, Ю. Ю. Віцюк, К.т.н., Т. А. Роїк, д.т.н., професор, П. О. Киричок, д.т.н., професор, НТУУ «КПІ», Київ, Україна

В статье приведены результаты теоретических исследований динамического упрочнения и параметров наклепа в тонких поверхностных слоях композитных деталей трения для типографических машин, изготовленных из новых износостойких композитных материалов на основе отходов инструментальных сталей и обработанных методами тонкого абразивного шлифования.

In the article the theoretical researches of dynamical strength and such quality parameters of surfaces like cold-work strengthening in the thin layers composite friction pieces for printing machines, which were manufactured from new wear-resistance composite materials on the base of instrumental steels wastes and finished by fine abrasive grinding methods have been presented.

\section{Вступ}

Безперервний розвиток поліграфічної галузі народного господарства України вимагає створення та впровадження у виробництво високопродуктивної друкарської техніки, здатної успішно працювати зі швидкостями роботи вузлів та агрегатів, які у 2-3 рази перевищують існуючи показники. Такі умови експлуатації інтенсифікують процеси зношування деталей тертя, яких є чимало у сучасних високошвидкісних поліграфічних машинах (підшипники ковзання, що працюють зі швидкостями обертання до 400 об./хв. і питомими тисками 2-4 МПа, направляючі лотки, лапи захватів, орієнтатори та ін.).
Підвищений знос деталей пар тертя обумовлює зниження таких важливих для виробників показників надійності, як коефіцієнт готовності техніки, термін безвідмовної служби, довговічність та ремонтоздатність.

Здолати наведені негативні явища можливо, якщо використати для виготовлення деталей тертя друкарських машин найновіші високозносостійкі композитні матеріали [1-4], створені в останні роки науковцями, та застосовувати найсучасніші технологічні процеси фінішного оброблення, які формують необхідні показники якості поверхонь тертя, забезпечуючи їх високу зносостійкість [5-13]. 
Усі дослідження процесів надтонкої обробки поверхонь деталей тертя, зокрема високошвидкісних зносостійких підшипників ковзання, методами тонкого абразивного [5-8], алмазного [9], ельборового [10] шліфування, хонінгування [11] та магнітно-абразивного оброблення (МАО) дрібнозернистими феро-керамічними порошками [12] виконувались з урахуванням дії факторів обробки у статиці і не враховували специфіки дії динаміки процесу різання матеріалів.

Адже відомо, що, наприклад, технологічний процес шліфування відбувається зі швидкостями обертання кругу 20$50 \mathrm{~m} / \mathrm{c}$, а ці значення швидкостей на порядок перевищують швидкості динамічних випробувань на міцність $(\approx 1-1,5 \mathrm{~m} / \mathrm{c})$ металевих матеріалів [11].

Це суттєво впливає на розуміння складних явищ, які відбуваються у поверхневих шарах деталей i, які формують кінцеві значення параметрів поверхонь тертя. Зазначимо, що при динамічному навантаженні процес зрізання тонких стружок відбувається зі збільшення дії силового та температурного полів $[7,8]$, пластичного деформування [6] (в першу чергу, внаслідок ускладнення оброблюваності високолегованих композитних матеріалів, до складу яких входять вольфрам, ванадій, молібден, цезій, нікель, цирконій [1-4]) і різкого збільшення тертя ріжучих зерен абразивного кругу, що наносять динамічні удари 3 великими швидкостями по мікрооб'єму металу, що зрізається з поверх- невого шару деталі. Тому дослідження динамічного зміцнення поверхонь композитних деталей тертя друкарських машин тонким шліфуванням $€$ актуальною задачею, що, безумовно, має не лише теоретичне, а i, що не менш важливо, практичне значення.

\section{Постановка проблеми}

На ступінь зміцнення поверхневого шару основного металу при тонкому шліфуванні абразивними, алмазними, кубонітовими чи ельборовими інструментами найсуттєвіший вплив чинять температурний та динамічний фактори, які призводять до виникнення пластичної деформації, що в свою чергу супроводжує утворення наклепу. Цьому явищу властиві: підвищення показників опору металу деформації (поверхнева твердість металу); зниження границь пластичної та ударної в'язкості; зростання границь текучості тощо. Крім того, явище наклепу сприяе зростанню межі втомленої міцності деталей, спричинених виникненням стискуючих внутрішніх залишкових напружень, тому встановлення оптимальних технологічних режимів для процесу оздоблювальної обробки, які сприяють зміцненню поверхневого шару, необхідно проводити на основі ґрунтових теоретичних досліджень.

На даний час науковцями розроблена значна кількість математичних залежностей для визначення експлуатаційних властивостей деталей машин, поверхні яких попередньо зміцнювались методами ме- 
ханічного оброблення [14-17]. Однак, більшість з розроблених залежностей, як правило, носять емпіричний характер, а представлені теоретичні розробки не завжди враховують стан поверхневого шару виробу всіх його геометричних та фізико-механічних аспектів. Так, підхід до розрахунку поверхневого зміцнення процесу зміцнююче-калібруючого оброблення, що наведений в роботі [18], не дозволяє теоретично враховувати впливи геометричних параметрів індентора та фізикомеханічних характеристик стану поверхні в місцях контактування.

Враховуючи певну загальну незавершеність у розгляді даного питання, метою статті $є$ спроба розробити і дослідити універсальні теоретичні залежності для встановлення ступеню поверхневого зміцнення деталей та товщини наклепаного шару металу, який підлягав абразивній обробці з врахуванням особливостей геометрії алмазно-абразивного зерна, миттевого високотемпературного впливу і фізико-механічних властивостей матеріалу обробки.

Як відомо, за умови будьяких методів механічного оброблення деталей машин на зміцнення їх поверхневого шару, основний вплив чинять силовий та температурний фактори [13]. Показником рівня наклепу поверхні від дії силового впливу прийнято вважати ступінь зміцнення $\mathrm{k}_{3}$ та товщину зміцненого шару $h_{Y}^{\delta}$. Вплив температурного фактору на ступінь зміцнення в даний час не ви- дається можливим описати математично у зв'язку із складністю врахування великої кількості фізико-механічних характеристик матеріалу і технологічних факторів, тому зміцнення матеріалу під впливом локального теплового джерела, яким $є$ удар абразивного зерна по поверхні оброблення зі швидкістю 20-50 м/с розглядатимемо як процес гартування, встановлюючи товщину зміцненого поверхневого шару $h_{Y}^{\top}$.

Аналіз результатів експериментальних досліджень поверхневого зміцнення динамічним впливом, проведених методом втиснення індентора сферичної форми вказали, що розміри залишеного сліду менші, ніж були у процесі контакту. Якщо розмір залишеного сліду використовувати як поверхню занурення індентора, то розмір цієї поверхні виявиться заниженим на 4,4 \% [20], що підтверджується теорією Герца стосовно відношення величини навантаження до твердості матеріалу поверхні контактування.

Відомо, що показник твердості матеріалу, за Беренелем, знаходиться залежно від границь текучості $\sigma_{\mathrm{T}}\left(\mathrm{HB}=3 \sigma_{\mathrm{T}}\right)$, де зростання $\sigma_{\mathrm{T}}$ характеризується коефіцієнтом стиснення $\mathrm{C}_{\mathrm{CT}}$, значення якого встановлюється відношенням середнього тиску на площині контакту $\mathrm{P}_{\mathrm{C}}$ до $\sigma_{\mathrm{T}}\left(\mathrm{C}_{\mathrm{CT}}=\mathrm{P}_{\mathrm{C}} / \sigma_{\mathrm{T}}[21]\right)$, згідно чого (з врахуванням відсотків пластичного відновлення металу), встановлено:

$$
\begin{gathered}
\mathrm{P}=\mathrm{C}_{\mathrm{CT}} \cdot \sigma_{\mathrm{T}}=(1-0,044) \cdot 3 \sigma_{\mathrm{T}}= \\
=2,868 \cdot \sigma_{\mathrm{T}} \approx \mathrm{HB} .
\end{gathered}
$$


Із прикладанням зусилля $\mathrm{P}$ в центрі площини контакту починає виникати пластична деформація, однак із поступовим зануренням індентора в матеріал, твердість його поверхневого шару відрізнятиметься від твердості серцевини металу. Це викликає зміщення початку пластичної деформації в область нижчих тисків. Отже, тиск робочої поверхні індентора, здатного викликати початок процесу пластичного деформування, визначатиметься наступною залежністю

$$
P_{C}=2,868 \sigma_{T}\left(H_{\mu_{T}}\right),
$$

де $\mathrm{H}_{\mu_{\mathrm{T}}}-$ мікротвердість серцевини основного матеріалу.

Модель зміцнення поверхневого шару

Після настання процесу текучості в центральній частині контактуючої площини індентора, периферійна його робоча поверхня зустрічає опір зближенню, величина якого зменшується 3 охопленням пластичною деформацією всього об'єму матеріалу, що витискується сферичною поверхнею індентора. Із ростом контактних наближень зона пластичної деформації зростатиме, поширюючись на всю площину контакту і переміщуючись від поверхні вглиб металу. Процес текучості під всією поверхнею контакту поширюється лише тоді, тиск у місцях найменших дотичних напружень досягатиме величини $\mathrm{P}=\mathrm{H}_{\mu_{\mathrm{T}}}$.

Вплив силових факторів на якісне формування поверхневого шару металу (внаслідок дії на нього абразивних зерен шліфувального кругу) супроводжується динамічним контактуванням одночасно багатьох зерен. Фактично в даному процесі відбувається динамічний удар, в результаті чого індентор (зерно) заглиблюється у поверхневий шар металу із зусиллям, значення якого пов'язане з розмірами утвореного на поверхні відбитку і визначається згідно залежності Мейєра [20]

$$
\begin{aligned}
& \mathrm{P}=\frac{\mathrm{C}_{\mathrm{cT}} \cdot \mathrm{H}_{\mu \mathrm{o}} \cdot \mathrm{k}_{\mathrm{ci}} \cdot \sigma_{\mathrm{T}} \cdot \mathrm{A}_{\mathrm{iK}}}{\mathrm{H}_{\mu_{\mathrm{m}}}}= \\
& =2,868 \cdot \mathrm{A}_{\mathrm{ik}} \cdot \mathrm{k}_{\mathrm{ci}} \cdot \sigma_{\mathrm{T}} \frac{\mathrm{H}_{\mu_{0}}}{\mathrm{H}_{\mu_{\mathrm{n}}}}
\end{aligned}
$$

де $\mathrm{k}_{\mathrm{ci}}$ - коефіцієнт степеню зміцнення матеріалу обробки; $\mathrm{H} \mu_{\circ}$ - мікротвердість поверхневого шару; $\mathrm{A}_{\text {iк }}$ - площа контакту робочої поверхні одиничного індентора з поверхнею, величина якої встановлена, як половина площі бічної поверхні стисненого еліпсоїда за формулою

$$
A_{\text {iK }}=0,5 \pi\left(2 R_{11} b_{1}+a_{1}^{2}\right),
$$

де $a_{1}$ i $b_{1}$ - відповідно, мала й велика півосі перерізу сферичного сліду, розміри яких визначаються згідно [20].

Вираз для встановлення ступеню зміцнення поверхневого шару основного металу виробу має вигляд

$$
k_{c i}=0,222 \frac{H_{\mu_{m}}\left[\begin{array}{l}
m V_{n \delta}^{2}-\aleph_{1}\left(P_{N}^{2}-N_{S}^{2}\right)- \\
-\aleph_{1} C_{1}\left(P_{N}-N_{s}\right)
\end{array}\right]}{P_{N}^{1 / 3} \cdot H_{\mu_{0}} \cdot \sigma_{T} \cdot k_{1} \cdot}
$$


Коли зміцнення поверхні здійснюється одночасно сумісним впливом теплового удару зерна і динамічного контактування, доцільніше встановлювати не рівень наклепу шляхом визначення коефіцієнту $\mathrm{k}_{\text {зм}}$, a мікротвердість поверхневого шару і глибину його залягання, що представляє реальнішу картину стану металу, адже на відміну хаотичного виникнення теплових ударних розрядів контактування 3 одночасною дією десятків абразивних зерен забезпечує рівномірне контактування $з$ всією поверхнею, що слугує надійним гарантом рівномірної взаємодії.

Результат динамічного контактування показав, що пластичне деформування поверхні всією площиною контакту в середньому відповідає деформаціям стиснення, утворених під відбитком одиничного зерна. Навколо утвореної залишкової вм'ятини виникає пластично деформована область, яка поширюється у поверхневому шарі на товщину $\mathrm{h}_{\mathrm{z}}^{\delta}$. На межі утвореної замкненої області виконується умова пластичності згідно тверджень Генкі-Мізеса, тобто, що величина внутрішнього напруження переважає границі текучості [21], для даного методу контактної взаємодії отримано

$h_{\mathrm{Z}}=k_{\mathrm{Y}}\left(0,5 \cdot \mathrm{P} \cdot \sigma_{\mathrm{T}}^{-1}-1,42 \mathrm{a}_{1} \mathrm{~b}_{1}\right)^{0,5}$

а враховуючи, що $\mathrm{k}_{\mathrm{Y}}=1-0,5[1$ - $\left.\left(b_{1} / a_{1}\right)\right]^{4}$, а для композитів [1-4] $\sigma_{\mathrm{T}}=0,2 \cdot \mathrm{H}_{\mathrm{g}}$, та умови незмінності відношення між $\sigma_{\mathrm{T}} \mathrm{i}$ дійсною твердістю серцевини основного металу від швидкості взаємного контактування, отримана аналітична залежність для становлення дійсної товщини зміцненого шару

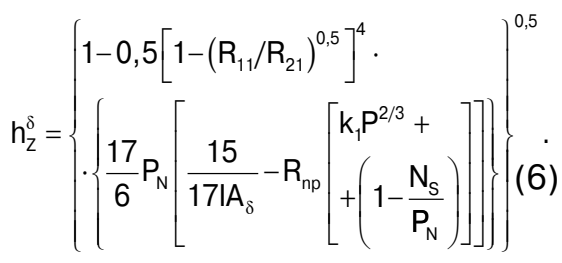

Після переміщення поверхнею теплового джерела від удару зерна починається процес охолодження даного об'єму металу. Висока теплопровідність основного металу сприяє швидкому відводу тепла (швидкість охолодження) із зони миттєвого нагрівання незначного за об'ємом (порівняно із загальним об'ємом виробу) поверхневого шару, причому швидкість охолодження більша швидкості гартування, тобто:

$\mathrm{dT}_{\mathrm{A}} /(\mathrm{dt}) \prec\left(\mathrm{dT}_{\mathrm{Ox}}\right) / \mathrm{dt} \quad$ [20], що для даного технологічного процесу не потрібне застосування примусового охолодження, хоча аеродинамічні особливості шліфувального кругу незалежно сприяють ефективному охолодженню нагрітої поверхні [13].

Процес поширення теплоти від миттєвого точкового джерела в необмеженому теплопровідному тілі проходить відповідно диференційного рівняння теплопровідності Фур'є

$$
\left(\frac{\partial \mathrm{T}}{\partial \mathrm{t}}\right)=\mathrm{a} \nabla^{2} \mathrm{~T},
$$

виразивши останнє відносно оператора Лапласа, як тримірне 
поле в декартових координатах, отримано:

$$
\nabla^{2} \mathrm{~T}=\frac{\partial^{2} \mathrm{~T}}{\partial^{2} \mathrm{X}}+\frac{\partial^{2} \mathrm{~T}}{\partial^{2} \mathrm{Y}}+\frac{\partial^{2} \mathrm{~T}}{\partial^{2} \mathrm{Z}} .
$$

Таке твердження стосується лише припущення, що тіло $є$ необмеженим (з відсутніми граничними умовами), а отже процес поширення теплоти на будь-які значні відстані від джерела підвладний лише рівнянню теплопровідності. Диференційне рівняння (7), за умови витримування граничних обмежень елементарного об'єму ( $\mathrm{t}=0$; $0<\mathrm{X}<\mathrm{dX} ; 0<\mathrm{Y}<\mathrm{dY}$; $0<\mathrm{Z}<\mathrm{dZ}$ ), задовольняє наступне [19].

$$
\mathrm{T}(\mathrm{R}, \mathrm{t})=\frac{\mathrm{Q}}{\mathrm{C}_{\gamma}(4 \pi \mathrm{at})^{3 / 2}} \mathrm{e}^{-\frac{\mathrm{R}^{2}}{4 \mathrm{at}}},
$$

де $R^{2}=\left(X^{2}+Y^{2}+Z^{2}\right)-$ квадрат сферичного радіуса $R$, який відображає дійсну відстань точки просторового поля (X, Y, Z) від початкових координат; $\mathrm{t}$ час впливу теплового джерела.

Із зростанням швидкості переміщення кругу $\mathrm{V}_{\text {кр }}$ температурний максимум $\mathrm{T}_{\max }$ 3совується до краю теплового джерела, в сторону протилежну напряму його руху. Якщо $\mathrm{V}_{\mathrm{kp}}=$ const, то через певний час температурне поле стабілізується, а поширення теплоти залежить лише від співвідношення тривалості теплонасичення поверхневого шару та терміну переміщення джерела поверхнею оброблення з моменту зародження теплового джерела.

Процес нагрівання напівнескінченного тіла рухомим тепловим джерелом, густина потужності якого розподіляється згідно закону Гауса, описується диференційним рівнянням (6), вираженим у наступному вигляді [19].

$$
\begin{aligned}
& \frac{\partial^{2} \mathrm{~T}}{\partial^{2} \bar{X}}+\frac{\partial^{2} \mathrm{~T}}{\partial^{2} \overline{\mathrm{Y}}}+\frac{\partial^{2} \mathrm{~T}}{\partial^{2} \overline{\mathrm{Z}}}+ \\
& +2 \mathrm{Pe} \frac{\partial \mathrm{T}}{\partial \overline{\mathrm{X}}}-\frac{\partial \mathrm{T}}{\partial \mathrm{F}_{\mathrm{o}}}=0
\end{aligned}
$$

де $\mathrm{Pe}=(\mathrm{SL}) / \mathrm{a}=\left(\mathrm{V}_{\delta} \mathrm{r}_{\mathrm{cл}}\right) / 2 \mathrm{a}-$ вираз критерія Пекле з точки зору швидкоплинного переміщення теплового розряду; $F_{0}=(a t) / r_{\text {ne }}^{2}$ - критерій Фурьє;

В останньому виразі:

$$
\begin{aligned}
& \mathrm{T}=\left(\mathrm{T}_{\mathrm{H}}-\mathrm{T}_{\mathrm{n}}\right) / \mathrm{T}_{\mathrm{c}} \\
& \mathrm{T}_{\mathrm{c}}=\left[\mathrm{W} /\left(2 \lambda \mathrm{r}_{\mathrm{cл}}\right)\right] \cdot(1 / \pi)^{0,5} ; \\
& \mathrm{W}=\eta / \mathrm{U} ; \\
& \mathrm{X}=\mathrm{X} / \mathrm{r}_{\mathrm{cл}} ; \mathrm{Y}=\mathrm{Y} / \mathrm{r}_{\mathrm{cл}} ; \mathrm{Z}=\mathrm{Z} / \mathrm{r}_{\mathrm{cл}},
\end{aligned}
$$

де $\mathrm{T}_{\mathrm{H}}$ і $\mathrm{T}_{\mathrm{n}}$ - відповідно температура нагрівання поверхневого шару в j-й точці за час $\mathrm{t}$ дії теплового джерела та вихідна кімнатна температура тіла; $\mathrm{T}_{\mathrm{c}}$ гранична температура з нормальним розподіленням центральної точки плям дуги; W ефективна потужність теплового джерела; $\eta$ - тепловий ККД джерела ( $\eta=0,7$ [19]); X, Y, Z дійсні координати ј-ої точки.

Значення температури нагрівання поверхні на осі OX (рис. 1) встановлюється згідно

$$
\mathrm{T}(0,0, \mathrm{t})=\frac{\mathrm{W}}{4 \pi \lambda r_{\mathrm{ne}}\left[1+\left(\mathrm{V}_{\mathrm{kp}}\right) / 80\right]^{0,5}}
$$

У процесі теплового зміцнення поверхні температура поверхневого шару металу $\mathrm{T}(0,0, \mathrm{t})$ повинна бути вищою температури гартування $\mathrm{T}_{\Gamma}$, але перевищувати температуру

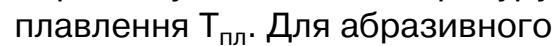


оброблення це означає, що гартуватиметься шар металу розташований слідом-лункою, утвореною абразивним зерном, тобто, повинна витримуватись умова, що

$$
\mathrm{T}_{\Gamma}<\mathrm{T}(0,0, \mathrm{t}) \leq \mathrm{T}_{\text {пл }}
$$

Наведемо зміну температури у наступному вигляді:

$$
\begin{array}{r}
\mathrm{T}(\mathrm{X}, \mathrm{Y}, \mathrm{t})=\mathrm{T}(0,0, \mathrm{t}) \times \\
\times \exp \left[\begin{array}{l}
\frac{\mathrm{Z}^{2}}{(8 \mathrm{ar}) / \mathrm{V}_{\delta}}- \\
-\frac{\mathrm{Y}^{2}}{(8 a r) / \mathrm{N}_{\mathrm{kp}}+r}
\end{array}\right]
\end{array}
$$

або

$$
\begin{aligned}
& \frac{T(X, Y, t)}{T(0,0, t)}= \\
& =\exp \left[\begin{array}{l}
\frac{Z^{2}}{(8 a r) / V_{\delta}}- \\
-\frac{Y^{2}}{(8 a r) / N_{\mathrm{kp}}+r}
\end{array}\right],
\end{aligned}
$$

а після логарифмування отримано

$$
\begin{gathered}
\frac{\mathrm{Y}^{2}}{\left[(8 a r) / \mathrm{N}_{\delta}+r\right] \ln \mathrm{X}}+ \\
+\frac{\mathrm{Z}^{2}}{\left[(8 a r) / \mathrm{N}_{\mathrm{kp}}+r\right] \ln \mathrm{X}}=1, \\
\text { де } \quad \mathrm{X}=\frac{\mathrm{T}(0,0, \mathrm{t})}{\mathrm{T}(\mathrm{X}, \mathrm{Y}, \mathrm{t})} .
\end{gathered}
$$

Остання залежність підтверджує встановлену у [19] форму сліду на поверхні від теплового розряду вказавши, що ізотерма будь-якої температури нагрівання $\mathrm{T}(\mathrm{Y}, \mathrm{Z}, \mathrm{t})=\mathrm{T}$ являє собою півеліпс. Велика вісь ізо- термічного півеліпсу паралельна осі OY, а менша - oci OZ, а дані півеліпси мають однакове співвідношення осей, рівне:

$$
\left[1+(8 \mathrm{a}) / \mathrm{V}_{\mathrm{kp}}\right]^{0,5}
$$

звідки максимальні розміри зони поверхневого температурного зміцнення на осі ОY за умови, що $\mathrm{T}(X, Z, T)=\mathrm{T}_{\Gamma}$ та In $>0$, визначаються наступними залежностями:

$$
\begin{aligned}
& \mathrm{h}_{\mathrm{Z}}^{\top}=\mathrm{Z}=\left\{\frac{8 \mathrm{ar}}{\mathrm{V}_{\mathrm{kp}}} \ln \left[\frac{\mathrm{W}}{4 \pi \mathrm{r} \lambda \mathrm{T}\left(1+\left(\mathrm{V}_{\delta} \mathrm{r}\right) / 8 \mathrm{a}\right)^{0,5}}\right]\right\}^{0,5}, \\
& \mathrm{Y}=\left\{( \frac { 8 \mathrm { ar } } { \mathrm { V } _ { \delta } } + \mathrm { r } ) \operatorname { l n } \left[\frac{\mathrm{W})}{\left.\left.4 \pi \mathrm{r} \lambda \mathrm{T}\left(1+\left(\mathrm{V}_{\mathrm{kp}} \mathrm{r}\right) / 8 \mathrm{a}\right)^{0,5}\right]\right\}(17)}\right.\right.
\end{aligned}
$$

Вираз (17) встановлює розміри області температурного гартування лише у випадку впливу на поверхню елементарного (одиночного) абразивного зерна, фактично не враховуючи теплового впливу сусідніх джерел в цілому. Користуватись отриманою залежністю доцільним $€$ проведення експериментальних досліджень для порівнювання одержаних аналітичних рахунків з результатами експериментів.

Для отримання узагальненого теоретично обчисленого результату зміцнення поверхневого шару матеріалу внаслідок динамічної дії абразивного зерна в останні наведені залежності слід підставляти отримані рішення вирази $(8,9,10)$ та встановивши згідно рис. швидкість переміщення поверхнею оброблення шліфувального кругу $\mathrm{V}_{\mathrm{kp}}$, величина якої визначається згідно виразу (16) 


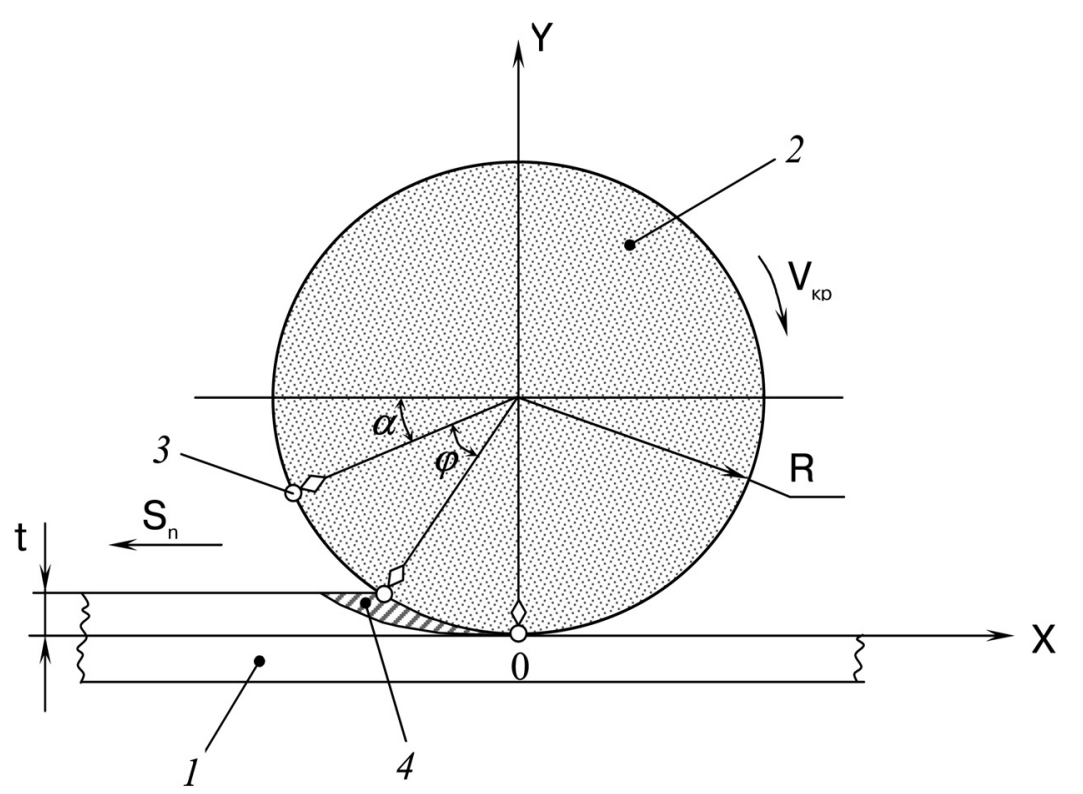

Схема динамічного зміцнення поверхневого шару композитного матеріалу при шліфуванні: 1 - композитна деталь тертя; 2 - шліфувальний круг; 3 - ріжуче абразивне зерно; 4 - елемент стружки, що зрізується поодиноким зерном; $\mathrm{t}$ - глибина різання, мкм; $\mathrm{S}_{\mathrm{n}}$ - поздовження, м/Хв.; $\mathrm{V}_{\text {кр }}$ - швидкість шліфувального кругу, м/с; R - радіус кругу; $\alpha, \varphi-$ кути врізання, град.

$V_{k p}=t \times c o s\left[\arccos \left(\frac{R-t}{R}\right)-\frac{S_{n}}{R t}\right]$,

a, відповідно, і часу Т ефективної дії ріжучого зерна

$$
\mathrm{T}=\frac{\mathrm{V}_{\mathrm{kp}}}{\mathrm{R}^{2}}\{[2 \mathrm{t} \times(\mathrm{R}-\mathrm{t})] / 2 \mathrm{R}\}^{0,5} .
$$

Наведений вираз (16) € універсальним, що дозволяє крім безпосереднього визначення товщини $\mathrm{h}_{\mathrm{z}}$ зміцненого поверхневого шару матеріалу встановлювати, задавшись заздалегідь необхідною твердістю матеріалу і товщиною зміцненого шару, ефективні технологічні режими $\left(\mathrm{V}_{\mathrm{kp}}, \mathrm{t}, \mathrm{S}_{\mathrm{n}}\right.$ тощо) процесу оброблення, тобто, отримана залежність є теоретичною моделлю методу математичного прогнозування, практичне застосування якої дозволяє попередньо задаватись експлуатаційними характеристиками поверхонь деталей.

\section{Експериментальні дослідження}

Для підтвердження конструктивності одержаних теоретичних залежностей проведено експериментальне визначення для композиційного сплаву на основі відходів інструментальної сталі [1] товщини зміцненого шару $h_{z}$ з необхідною твердістю HВ 278, що досягається нагріванням металу до температури $660{ }^{\circ} \mathrm{C}$ [22]. Приймаємо, 
що поверхня уражена атмосферним і тонким корозійними шарами у вигляді окалини з середньою товщиною покриття $\mathrm{h}_{\mathrm{OK}}=6,5 \cdot 10^{-4} \mathrm{M}$ (фізичні властивості: $\lambda_{\mathrm{OK}}=3,87 \mathrm{BT} /\left(\mathrm{M}^{\circ}{ }^{\circ} \mathrm{C}\right)$; $\mathrm{a}_{\mathrm{OK}}=$ $=0,11 \cdot 10^{-4} \quad \mathrm{M}^{2} / \mathrm{c} ; \quad \mathrm{C}_{\mathrm{OK}}=$ $=783$ Дж $/\left(\mathrm{Kг}{ }^{\circ} \mathrm{C}\right) ; \mathrm{C}_{\gamma \mathrm{OK}}=5,02$ Дж/(м $\left.{ }^{3 \cdot{ }^{\circ}} \mathrm{C}\right)$ [19] та тонким вкрапленнями бруду $-\mathrm{h}_{\mathrm{i}}=5,0 \cdot 10^{-4} \mathrm{M}$ $\left(\lambda_{\mathrm{i}}=0,42 \mathrm{Bт} /\left(\mathrm{M}^{\circ}{ }^{\circ} \mathrm{C}\right) ; \mathrm{a}_{\mathrm{i}}=0,03 \cdot 10^{-4}\right.$ $\mathrm{m}^{2} / \mathrm{c} ; \mathrm{C}_{\mathrm{i}}=109$ Дж $/\left(\mathrm{\kappa} \Gamma^{\circ} \mathrm{C}\right) ; \mathrm{C}_{\gamma \mathrm{i}}=$ $=0,96$ Дж $/ \mathrm{M}^{\left.3 \cdot{ }^{\circ} \mathrm{C}\right)}$. Для серцевини основного металу: $\left(\lambda_{\mathrm{M}}=\right.$ $=4,02 \mathrm{BT} /\left(\mathrm{M}^{\circ} \mathrm{C}\right) ; \mathrm{a}_{\mathrm{M}}=0,08 \cdot 10^{-4}$ $\mathrm{m}^{2} / \mathrm{c} ; \mathrm{C}_{\mathrm{M}}=737$ Дж $\left./ \mathrm{кг} \cdot{ }^{\circ} \mathrm{C}\right) ; \mathrm{C}_{\gamma \mathrm{M}}=$ $=7,19$ Дж/ $\left./ \mathrm{m}^{3} \cdot{ }^{\circ} \mathrm{C}\right)$.

Технологічний процес тонкого абразивного шліфування поверхні деталі 3 нового композиційного матеріалу [1] для друкарських машин реалізується 3 використанням шліфувальних кругів на основі карбіду кремнію зеленого (G3C) зернистістю 14 мкм на еластичній гліфталевій зв'язці (Гл) з застосуванням таких режимів різання $\mathrm{V}_{\mathrm{kp}}=25 \mathrm{M} / \mathrm{c} ; \mathrm{S}_{\mathrm{n}}=2 \mathrm{M} / \mathrm{xB} ; \mathrm{t}=$ $=0,002 \mathrm{Mm}$.

Отримана твердість металу на глибині $h_{z}^{p}=8,8 \cdot 10^{-4}$ м. Це відповідає технічним вимогам.

Аналітично визначена товщина зміцненої поверхні прирівнювалась величиною, отриманою в результаті замірювання на шліфі зразка, експериментально обробленого за аналогічними показниками для матеріалу і технологічними режимами. Задана твердість металу отримана в середньому на глибині $h_{z}^{\text {een }}=9,3 \cdot 10^{-4}$ м. Відносна похибка розходження результатів становить 6,3 \%, що засвідчує про можливість практичного застосування наведеної методики математичного прогнозування поверхневого зміцнення.

Крім наведеного підтвердження, слід вказати, що за даною методикою, при умові попереднього призначення товщини зміцненого шару (у більшості випадків вказаного на робочих кресленнях деталей), встановлюється необхідна тривалість динамічного впливу Т, с

$$
\mathrm{T}=\frac{\pi\left(\mathrm{h}_{\mathrm{z}}^{\top}\right)^{2}}{4 \mathrm{a}}\left(\frac{\mathrm{t}}{\delta_{\varphi}-\delta_{\alpha}}\right)
$$

\section{Висновки}

Узагальнюючи результати наведених теоретичних досліджень та їх порівняння з результатами експериментів, доцільно зробити такі основні висновки:

1. Розроблена методика дозволяє $з$ високою імовірністю прогнозувати очікувані параметри якості поверхневого шару, зокрема степеню його зміцнення і глибини утвореного при обробці наклепу.

2. Показано, що параметри обробки (швидкість кругу Vкр, поздовжна подача $\mathrm{Sn}$, глибина різання t) суттєво впливають на якісні показники поверхні.

3. По встановленим режимам різання можливо ще до початку обробки деталі прогнозувати, які показники якості поверхневого шару будуть отримані по закінченні технологічного процесу.

4. У подальшому доцільним $€$ дослідження 3 врахуванням коефіцієнтів тертя по новим композитам різних абразивних ма- 
теріалів - карбіду кремнію зеленого, монокорунду, електро- корунду білого, алмазу синтетичного, кубоніту та ельбору.

1. Патент України № 102299, МПК С22С33/02. Антифрикційний композиційний матеріал на основі інструментальної сталі / Роїк Т. А., Гавриш А. П., Киричок П. О., Гавриш О. А., Віцюк Ю. Ю., опубл. 25.06.2013, Бюл. № 12. 2. Патент України № 60522, МПК С22С33/02 (2006.01). Підшипниковий композиційний матеріал на основі інструментальної сталі / Роїк Т. А., Гавриш А. П., Киричок П. О., Гавриш О. А., Віцюк Ю. Ю., Мельник О. О., опубл. 25.06.2011, Бюл. № 12. 3. Патент України № 30377, МПК С22С33/02 (2006.01). Порошковий антифрикційний матеріал на основі швидкорізальної сталі / Роїк Т. А., Гавриш А. П., Холявко В. В., Зора Б. П., опубл. 25.02.2008, Бюл. № 4. 4. Патент України № 60522, МПК С22С33/02. Підшипниковий композиційний матеріал на основі інструментальної сталі / Роїк Т. А., Гавриш А. П., Киричок П. О., Гавриш О. А., Віцюк Ю. Ю., опубл. 25.06.2011, Бюл. № 12. 5. Гавриш А. П. Вплив абразивного інструменту на шорсткість поверхонь композитних підшипників поліграфічної техніки при тонкому шліфуванні / А. П. Гавриш, А. В. Шевчук, Т. А. Роїк, В. А. Ковальов, Ю. Ю. Віцюк // Технологія і техніка друкарства. - 2012. - № 3. С. 119-127. 6. Гавриш А. П. Аналіз параметрів якості поверхонь підшипників ковзання з композитних сплавів для друкарських машин при абразивному шліфуванні / А. П. Гавриш, П. О. Киричок, Т. А. Роїк, Ю. Ю. Віцюк // Наукові вісті Національного технічного університету України «КПІ». - 2013. № 1. - С. 63-67. 7. Гавриш А. П. Силове поле при тонкому абразивному шліфуванні деталей тертя з нових композиційних сплавів для друкарської теніки / А. П. Гавриш, П. О. Киричок, Т. А. Роїк, Ю. Ю. Віцюк // Междунар. сб. науч. трудов «Прогрессивные технологии и системы машиностроения». Донецк : НТУ, 2013. - Вып. 1, 2(45). - С. 85-90. 8. Гавриш А. П. Дослідження температур при тонкому абразивному шліфуванні деталей з композитів на основі відходів інструментальних сталей / А. П. Гавриш, П. О. Киричок, Т. А. Роїк, Ю. Ю. Віцюк // Вісник Тернопільського технічного університету. 2013. - № 1. - С. 10-15. 9. Гавриш А. П. Вплив складу інструменту та режимів тонкого алмазного шліфування на шорсткість поверхонь композитних підшипників ковзання поліграфічних машин / А. П. Гавриш, Т. А. Роїк, П. О. Киричок, Ю. Ю. Віцюк // Наукові вісті Національного технічного університету України «КПІ». - 2013. - № 5. - С. 63-67. 10. Гавриш А. П. Вплив складу інструменту і режимів тонкого ельборового шліфування на шорсткість поверхонь композитних підшипників ковзання поліграфічних машин / А. П. Гавриш, Т. А. Роїк, П. О. Киричок, О. А. Гавриш, Ю. Ю. Віцюк // Вісник Житомирського державн. технологічн. університету. - 2012. № 3. - С. 27-37. 11. Гавриш А. П. Вплив технологічних факторів хонінгування на параметри шорсткості і точності поверхонь композитних підшипників ковзання поліграфічних машин / А. П. Гавриш, П. О. Киричок, Т. А. Роїк, Ю. Ю. Віцюк // Междунар. сб. научн. трудов «Прогрессивные технологии и системы машиностроения». - Донецк : НТУ, 2013. - Вып. 1, 2(46). - С. 56-64. 12. Гавриш А. П. Нові технології фінішного оброблення композиційних підшипників ковзання для жорстких умов експлуатації / А. П. Гавриш, О. О. Мельник, Т. А. Роїк, М. Г. Аскеров, О. А. Гавриш : Монографія. - К. : НТУУ «КПІ», 2012. - 196 с. 13. Гавриш А. П. Алмазноабразивна обробка магнітних матеріалів / А. П. Гавриш, П. П. Мельничук : Монографія. - Житомир : ЖДтУ. - 2004. - 552 с. 14. Бигер И. А. Общие алгоритмы решения задач теории упругости, пластичности и ползучести. 
Успехи механики деформируемых сред / И. А. Бигер. - М. : Наука, 1975. С. 51-73. 15. Гончаров Ю. В. Обработка металлов давлением / Ю. В. Гончаров. - М. : Металлургия, 1967. - С. 220. 16. Дрозд М. С. Расчеты глубины распределения пластической деформации в зоне контакта тел произвольной кривизны / М. С. Дрозд, А. В. Федоров, Ю. И. Сидякин // Вестник машиностроения. - 1977. - № 1. - С. 14-17. 17. Дрозд М. С. Инженерные расчеты упругопластической контактной деформации / М. С. Дрозд, М. М. Матлин, Ю. И. Сидякин. - М. : Машиностроение, 1986. - С. 224. 18. Кильчевский Н. А. Динамическое контактное сжатие твердых тел. Удар / Н. А. Кильчевский, А. О. Логинова. - Киев : Наукова думка, 1976. С. 315. 19. Гавриш О. А. Поверхнева очисно-зміцнююча обробка деталей у машинобудуванні / О. А. Гавриш. - К. : Наукова думка, 2003. - 283 с. 20. Одинцов Л. Г. Упрочнение и отделка деталей пластическим деформированием / Л. Г. Одинцов. - Справочник. - М. : Машиностроение, 1987. С. 328. 21. Панасюк В. В. Деякі контактні задачі теорії пружності / В. В. Панасюк, М. І. Теплий. - Київ : Наукова думка. - 1975. - С. 195. 22. Лахтин Ю. М. Материаловедение / Ю. М. Лахтин, В. П. Леонтьева. - М. : Машиностроение, 1990. - 528 с.

1. Patent Ukrainy № 102299, MPK S22S33/02. Antyfryktsiinyi kompozytsiinyi material na osnovi instrumentalnoi stali / Roik T. A., Havrysh A. P., Kyrychok P. O., Havrysh O. A., Vitsiuk lu. lu., opubl. 25.06.2013, Biul. № 12. 2. Patent Ukrainy № 60522, MPK S22S33/02 (2006.01). Pidshypnykovyi kompozytsiinyi material na osnovi instrumentalnoi stali / Roik T. A., Havrysh A. P., Kyrychok P. O., Havrysh O. A., Vitsiuk lu. lu., Melnyk O. O., opubl. 25.06.2011, Biul. № 12. 3. Patent Ukrainy № 30377, MPK S22S33/02 (2006.01). Poroshkovyi antyfryktsiinyi material na osnovi shvydkorizalnoi stali / Roik T. A., Havrysh A. P., Kholiavko V. V., Zora B. P., opubl. 25.02.2008, Biul. № 4. 4. Patent Ukrainy № 60522, MPK S22S33/02. Pidshypnykovyi kompozytsiinyi material na osnovi instrumentalnoi stali / Roik T. A., Havrysh A. P., Kyrychok P. O., Havrysh O. A., Vitsiuk lu. lu., opubl. 25.06.2011, Biul. № 12. 5. Havrysh A. P. Vplyv abrazyvnoho instrumentu na shorstkist poverkhon kompozytnykh pidshypnykiv polihrafichnoi tekhniky pry tonkomu shlifuvanni / A. P. Havrysh, A. V. Shevchuk, T. A. Roik, V. A. Kovalov, lu. lu. Vitsiuk // Tekhnolohiia i tekhnika drukarstva. - 2012. - № 3. - S. 119-127. 6. Havrysh A. P. Analiz parametriv yakosti poverkhon pidshypnykiv kovzannia z kompozytnykh splaviv dlia drukarskykh mashyn pry abrazyvnomu shlifuvanni / A. P. Havrysh, P. O. Kyrychok, T. A. Roik, lu. lu. Vitsiuk // Naukovi visti Natsionalnoho tekhnichnoho universytetu Ukrainy «KPI». - 2013. - № 1. - S. 63-67. 7. Havrysh A. P. Sylove pole pry tonkomu abrazyvnomu shlifuvanni detalei tertia z novykh kompozytsiinykh splaviv dlia drukarskoi teniky / A. P. Havrysh, P. O. Kyrychok, T. A. Roik, lu. lu. Vitsiuk // Mezhdunar. sb. nauch. trudov «Progressivnye tehnologii i sistemy mashinostroenija». - Doneck : NTU, 2013. - Vyp. 1, 2(45). - S. 85-90. 8. Havrysh A. P. Doslidzhennia temperatur pry tonkomu abrazyvnomu shlifuvanni detalei z kompozytiv na osnovi vidkhodiv instrumentalnykh stalei / A. P. Havrysh, P. O. Kyrychok, T. A. Roik, lu. lu. Vitsiuk // Visnyk Ternopilskoho tekhnichnoho universytetu. - 2013. - № 1. - S. 10-15. 9. Havrysh A. P. Vplyv skladu instrumentu ta rezhymiv tonkoho almaznoho shlifuvannia na shorstkist poverkhon kompozytnykh pidshypnykiv kovzannia polihrafichnykh mashyn / A. P. Havrysh, T. A. Roik, P. O. Kyrychok, lu. lu. Vitsiuk // Naukovi visti Natsionalnoho tekhnichnoho universytetu Ukrainy «KPI». 2013. - № 5. - S. 63-67. 10. Havrysh A. P. Vplyv skladu instrumentu i rezhymiv tonkoho elborovoho shlifuvannia na shorstkist poverkhon kompozytnykh pidshypnykiv kovzannia polihrafichnykh mashyn / A. P. Havrysh, T. A. Roik, 
P. O. Kyrychok, O. A. Havrysh, lu. lu. Vitsiuk // Visnyk Zhytomyrskoho derzhavn. tekhnolohichn. universytetu. - 2012. - № 3. - S. 27-37. 11. Havrysh A. P. Vplyv tekhnolohichnykh faktoriv khoninhuvannia na parametry shorstkosti i tochnosti poverkhon kompozytnykh pidshypnykiv kovzannia polihrafichnykh mashyn / A. P. Havrysh, P. O. Kyrychok, T. A. Roik, lu. lu. Vitsiuk // Mezhdunar. sb. nauchn. trudov «Progressivnye tehnologii i sistemy mashinostroenija». Doneck : NTU, 2013. - Vyp. 1, 2(46). - S. 56-64. 12. Havrysh A. P. Novi tekhnolohii finishnoho obroblennia kompozytsiinykh pidshypnykiv kovzannia dlia zhorstkykh umov ekspluatatsii / A. P. Havrysh, O. O. Melnyk, T. A. Roik, M. H. Askerov, O. A. Havrysh : Monohrafiia. - K. : NTUU «KPI», 2012. - $196 \mathrm{~s}$. 13. Havrysh A. P. Almazno-abrazyvna obrobka mahnitnykh materialiv / A. P. Havrysh, P. P. Melnychuk : Monohrafiia. — Zhytomyr : ZhDTU. - 2004. 552 s. 14. Biger I. A. Obshhie algoritmy reshenija zadach teorii uprugosti, plastichnosti i polzuchesti. Uspehi mehaniki deformiruemyh sred / I. A. Biger. - M. : Nauka, 1975. - S. 51-73. 15. Goncharov Ju. V. Obrabotka metallov davleniem / Ju. V. Goncharov. - M. : Metallurgija, 1967. - S. 220. 16. Drozd M. S. Raschety glubiny raspredelenija plasticheskoj deformacii $\vee$ zone kontakta tel proizvol'noj krivizny / M. S. Drozd, A. V. Fedorov, Ju. I. Sidjakin // Vestnik mashinostroenija. - 1977. - № 1. - S. 14-17. 17. Drozd M. S. Inzhenernye raschety uprugoplasticheskoj kontaktnoj deformacii / M. S. Drozd, M. M. Matlin, Ju. I. Sidjakin. - M. : Mashinostroenie, 1986. - S. 224. 18. Kil'chevskij N. A. Dinamicheskoe kontaktnoe szhatie tverdyh tel. Udar / N. A. Kil'chevskij, A. O. Loginova. - Kiev : Naukova dumka, 1976. - S. 315. 19. Havrysh O. A. Poverkhneva ochysno-zmitsniuiucha obrobka detalei u mashynobuduvanni / O. A. Havrysh. - K. : Naukova dumka, 2003. - 283 s. 20. Odincov L. G. Uprochnenie i otdelka detalej plasticheskim deformirovaniem / L. G. Odincov. Spravochnik. - M. : Mashinostroenie, 1987. - S. 328. 21. Panasiuk V. V. Deiaki kontaktni zadachi teorii pruzhnosti / V. V. Panasiuk, M. I. Teplyi. - Kyiv : Naukova dumka. - 1975. - S. 195. 22. Lahtin Ju. M. Materialovedenie / Ju. M. Lahtin, V. P. Leont'eva. - M. : Mashinostroenie, 1990. - $528 \mathrm{~s}$.

Рецензент - О. М. Величко, д.т.н. професор, НТУУ «КПІ»

Надійшла до редакції 20.11.13 